\title{
Contents, Vol. 210, 1996
}

\section{No. 1}

Epidemiology of Blindness and Eye Disease

Krumpaszky, H.G.; Klauß, V. (Tübingen/München)

No. 2

Original Paper $\cdot$ Travau $\times$ originaux $\cdot$ Originalarbeiten

85 Long-Term Elevation of Intraocular Pressure after Neodymium:YAG Laser Posterior

Capsulotomy

Jahn, C.E.; Emke, M. (Kempten)

90 Laser Photocoagulation around the Foci of Toxoplasma Retinochoroiditis: A Descriptive

Statistical Analysis of 35 Patients with Long-Term Follow-Up

Desmettre, T.; Labalette, P.; Fortier, B.; Mordon, S.; Constantinides, G. (Lille) 95 Strabismus

Surgery in Ocular Myasthenia gravis

Ohtsuki, H.; Hasebe, S.; Okano, M.; Furuse, T. (Okayama) 101 Efficacy of a Novel H $\gamma$ drogel

Formulation in Human Volunteers

Mayer, H.; von der Ohe, N. (Hannover)

104 Vitreal Alterations in Retinitis pigmentosa: Biomicroscopic Appearance and Statistical

Evaluation

Vingolo, E.M.; Giusti, C; Forte, R.; Onori, P. (Rome)

108 Picture Resembling Hemicentral Retinal Vein Occlusion in the Acquired Immunodeficiency Syndrome: Is it Related to Cytomegalovirus?

Mansour, A.M.; Li, H.; Segal, E.I. (Galveston, Tex.)

112 Clinical and Immunogenetic Investigation of a Laotian Patient with Vogt-Koyanagi-

Harada's Disease

Shindo, Y.; Inoko, H.; Nakamura, S.; Onoé, K.; Inoue, T,; Ohno, S.

(Yokohama/Isehara/Sapporo)

115 Retrospective Survey of a Link between Cat and Dog Antigens and Allergic Conjunctivitis

Fujishima, H.; Shimazaki, J.; Yang, H.-Y.; Toda, I.; Tsubota, K. (Chiba/Tokyo)

119 Absorption of Topically Administered Ciprofloxacin, Ofloxacin and Gentamicin in the Inflamed Rabbit Eye

Behrens-Baumann, W. (Magdeburg)

Case Reports · Descriptions de cas · Fallberichte

123 Unilateral Acute Posterior Multifocal Placoid Pigment Epitheliopathy

Nakajima, N.; Noda, S.; Hayasaka, S. (Izumo/Toyama)

126 Congenital Hypertrophy of the Retinal Pigment Epithelium in the Macula

Nishikatsu, H.; Shiono, T. (Sendai)

129 Subretinal Fibrovascular Proliferation in Retinal Arteritis with Multiple Aneurysmal

Dilatations: A Case Report

Salvador, F.; Garcia-Arumí, J.; Amén, M.; Corcóstequi, B. (Barcelona) 
132 Anterior Ischemic Optic Neuropathy in a Patient with Positive Antinuclear Antibody and Lupus Anticoagulant Findings

Togashi, M.; Numata, K.; Yamamoto, S.; Hayasaka, S. (Toyama)

136 Book Review $\cdot$ Livre nouveau $\cdot$ Buchbesprechung 136 Announcement · Annonce ·

Ankündigung

No. 3

Original Paper $\cdot$ Travaux originaux $\cdot$ Originalarbeiten

137 Scanning Electron-Microscopic Studies of the Collagen

Architecture of the Human Sclera - Normal and Pathological Findings

Thale, A.; Tillmann, B.; Rochels, R. (Kiel) 142 SEM Studies of the Collagen Architecture of the

Human

Lamina cribrosa: Normal and Pathological Findings

Thale, A.; Tillmann, B.; Rochels, R. (Kiel) 148 Evaluation of Choroidal Neovascularization in

Age-Related

Macular Degeneration with Fluorescein and Indocyanine

Green Videoangiography

Atmaca, L.S.; Batioglu, F,; Atmaca, P. (Ankara) 152 HLA Typing and Retinitis pigmentosa

Castagna, I.; Famà, F.; Pettinato, G; Palamara, F.; Trombetta, C.J. (Messina)

155 Contrast Sensitivity with Monofocal and Bifocal Intraocular Lenses

Knorz, M.C.; Seiberth, V.; Ruf, M.; Lorger, C.V.; Liesenhoff, H. (Mannheim)

160 Grid Pattern Photocoagulation for Diabetic Macular Edema - Long-Term Visual Results

Kremser, B.G.; Kunze, C; Troger, J.; Ulmer, H.; Kieselbach, G.K. (Innsbruck)

163 Results of Surgery for Paralytic Exotropia due to Oculomotor Palsy

Maruo, T.; Iwashige, H.; Kubota, N.; Sakaue, T.; Ishida, T.; Honda, M.; Nemoto, Ý.; Usui, C.

(Tokyo)

168 Hyperbaric Oxygen Treatment for Macular Edema in Retinal Vein Occlusion: Relation to

Severity of Retinal Leakage

Kiryu, J.; Ogura, Y. (Kyoto/Kobe)

171 Influence of a Single HELP Application on Hemorheology and Retinal Hemodynamics

Haas, A.; Walzl, M.; Eckhardt, M.; Walzl, B.; Faulborn J.; Feigl, B. (Graz)

175 Effect of FK 506 Administered Topically versus Intramuscularly on Suppression of the

Corneal Immune Reaction in Rats

Okada, K; Sakata, H; Minamoto, A.; Fujihara, M. (Hiroshima)

Case Reports · Descriptions de cas · Fallberichte

180 The Inhibition of Vitamine K3 on Rabbit Fibroblast Proliferation in vitro

Liu, X.H.; Song, X.W.; Xu, Y.; Zhang, C. (Zhengzhou)

183

Ocular Complication in Congenital Erythropoietic Porphyria

Tanigawa, K; Takamura, N.; Nakata, K; Nagataki, S.; Yamashita, S. (Nagasaki)

186

A Case of Uveitis Associated with Chronic Active Epstein-Barr Virus Infection

Morishima, N.; Miyakawa, S.; Akazawa, Y.; Takagi, S. (Tokyo)

KAKGEH

E-Mail karger@karger.ch Fax+41 613061234 http://www.karger.ch

(C) 1996S. KargerAG, Basel 
The list of contents is available at: http://www.karger.ch/journals/oph/ophcont.htm

III

No. 4

Original Paper $\cdot$ Travau $\times$ originaux $\cdot$ Originalarbeiten

189 Indocyanine Green Angiography in Vitelliform Macular Lesions

Lanzetta, P.; Virgili, G.; Menchini, U. (Udine)

195 Electrical Responses from Locally Detached Retina and Its Recovery after Reattachment

Kim, S.-D.; Nao-i, N.; Maruiwa, F.; Sawada, A. (Miyazaki)

200 Colour Doppler Analysis of the Choroidal Circulation in Chronic Open-Angle Glaucoma

Cellini, M.; Possati, G.L.; Caramazza, N.; Caramazza, R. (Bologna)

203 Long-Term Results of Krupin-Denver Valve Implants in Filtering Surgery for Neovascular

Glaucoma

Mastropasqua, L.; Carpineto, P.; Ciancaglini, M; Zuppardi, E. (Chieti)

207 Evaluation of 6.5-mm BENT Incision to Reduce Postoperative Astigmatism

Nagata, S.; Yamada, K.; Matsuno, K.; Segawa, K. (Matsumoto/Nagano) 211 The Influence of

Dexamethasone $0.1 \%$ Eye Drops on Plasma Cortisol and ACTH Concentrations after Cataract

Surgery

Roters, S.; Aspacher, F.; Diestelhorst, M. (Köln)

215 Intravitreal Application of Ganciclovir in Rabbits: ERG and Electron-Microscopic Findings Moschos, M.; Vamvasakis, M.; Kontogeorgos, G.; Papantonis, F.; Panagakis, E.; Chatzis, V.

(Athens)

223 Tophus-Like, Conglomerated, Crystalline Calcification of the Sclera

Daicker, B. $\dagger$ (Basel)

229 Subfoveal Choroidal Neovascularization in Uveitis

Inagaki, M.; Harada, T.; Kiribuchi, T.; Ohashi, T.; Majima, J. (Toyoake) 234 Endogenous

Uveitis: An Analysis of 1,417 Cases

Pivetti-Pezzi, P.; Accorinti, ML; La Cava, M.; Colabelli Gisoldí, R.A.M.; Abdulaziz, MA.

(Rome)

Case Report · Description de cas · Fallbericht

239 Hemangioma of the Ciliary Body: A Case Report and Review of the Literature

Isola, V.M. (Trieste)

Obituary $\cdot$ Necrologique $\cdot$ Nachruf

244 Prof. B. Daicker $\dagger$

Meyer, P. (Basel)

280 Glaucoma, Capillaries and Pericytes. 5. Preliminary Evidence that Carbon Dioxide Relaxes Pericyte Contractile Tone Anderson, D.R.; Davis, E.B. (Miami, Fla.)

285 Blood Supply of the Optic Nerve Head

Hayreh, S.S. (Iowa City, Iowa) 296 Presence of a Contractile Cell Network in the Human

Choroid

Flügel-Koch, C; May, C.A.; Lütjen-Drecoll, E. (Erlangen-Nürnberg)

303 Aceclidine Effects on Outflow Facility after Ciliary Muscle Disinsertion

Hubbard, W.C.; Kee, C; Kaufman, P.L. (Madison, Wisc./Seoul)

308 Do Beta-Adrenoceptors and Serotonin 5-HT 1A Receptors Have Similar Functions in the

Control of Intraocular Pressure in the Rabbit?

Osborne, N.N.; Chidlow, G. (Oxford)

No. 6 
Original Paper $\cdot$ Travau $\times$ originaux $\cdot$ Originalarbeiten

315

Human Oscillatory Potentials: Components of Rod Origin

Janáky, M.; Goupland, S.G.; Benedek, G (Szeged/Alberta)

319

Balloon Dacryocystoplast $\gamma$ : An Alternative Treatment for Obstructed Tear Ducts

Liermann, D.; Berkefeld, J.; Fries, U,; Schalnus, R.W.; Gümpel, H. (Frankfurt a.M.)

325

lnterleukin-4 and IgE in Seasonal Allergic Conjunctivitis

Fujishima, H.; Shimazaki, J.; Takeuchi, T,; Saito, I.; Tsubota, K. (Chiba/Tokyo/Saitama)

329

Treatment of Cytomegalovirus Retinitis in AIDS Patients using Intravitreal Injections of Highly

Concentrated Ganciclovir

Baudouin, C; Chassain, C; Caujolle, C; Gastaud, P. (Nice)

336

Difficulties in Excluding the Diagnosis of Retinoblastoma in Cases of Advanced Coats' Disease:

A Clinicopathologic Report

341

Steidl, S.M.; Hirose, T.; Sang, D.; Hartnett, M.E. (Boston, Mass.) A Case of True Exfoliation

Majima, K.; Kousaka, M.; Kanbara, Y. (Aichi)

344 Survey of Risk Factors for Expulsive Choroidal Hemorrhage: Case Reports. Substantiation of the Risk Factors and Their Incidence

Sekine, Y.; Takei, K; Nakano, H.; Saotome, T.; Hommura, S. (Tsukuba/Hitachi)

348 Cost-Benefit Analysis of Diabetic Eye Disease

Matz, H.; Falk, M.; Göttinger, W.; Kieselbach, G. (Innsbruck)

Case Reports · Descriptions de cas · Fallberichte

No. 5

249 Preface

Lütjen-Drecoll, E. (Erlangen-Nürnberg)

250 Dedication

Lütjen-Drecoll, E. (Erlangen-Nürnberg)

251 The Concept of Chronic Open-Angle Glaucoma: A PersonalView

Drance, S.M. (Vancouver)

257 Glaucoma, Capillaries and Pericytes. 1. Blood Flow Regulation

Anderson, D.R. (Miami, Fla.)

263 Glaucoma, Capillaries and Pericytes. 2. Identification and Characterization of Retinal

Pericytes in Culture Anderson, D.R.; Davis, E.B. (Miami, Fla.)

269 Glaucoma, Capillaries and Pericytes. 3. Peptide Hormone Binding and Influence on

Pericytes

Ferrari-Dileo, G; Davis, E.B.; Anderson, D.R. (Miami, Fla.)

276 Glaucoma, Capillaries and Pericytes. 4. Beta-Adrenergic Activation of Cultured Retinal

Pericytes

Zschauer, A.O.A.; Davis, E.B.; Anderson, D.R. (Miami, Fla.)

354 Branch Retinal Vein Occlusion in a Patient with Waardenburg Syndrome

Kadoi, C; Hayasaka, S.; Yamamoto, S. (Toyoma)

358 Incomplete Occlusion of Central Retinal Artery in a Girl with Iron Deficiency Anemia 
Matsuoka, Y.; Hayasaka, S.; Yamada, K. (Shimane/Toyama)

361 Corneal Coloboma, Aphakia and Retinal Neovascularization with Anterior Segment Dysgenesis (Peter' Anomaly)

Gunderson, C.A.; Stone, R.; Peiffer, R.; Freedman, S. (Chapel Hill, N.C./Durham, N.C.) 367 Cavernous Hemangioma with Cone Dysfunction

Gündüz, K.; Özbayrak, N.; Okka, M,; Okudan, S.; Zengin, N. (Konya)

Letter to the Editor · Lettre · Leserbrief

372 Comment on the Paper of Doctors Rouhiainen, Leino andTeräsvirta

Hollo, G. (Budapest)

Book Review $\cdot$ Livre nouveau $\cdot$ Buchbesprechung

Author Index 376 Subject Index

IV

O.Vol. Ophthalmologica Vol. 210

1996

Contents 